\title{
Study on Postmodernism Nabokov's Literature under Chinese Cross-border Perspective
}

\author{
Yanmei Kong \\ Heihe University \\ Heihe, China 164300
}

\author{
Zhichun Zhu \\ Heihe University \\ Heihe, China 164300
}

\begin{abstract}
Vladimir Nabokov was the greatest bilingual writer of the 20th century. China's Nabokov research has experienced three stages include the germination in $1980 \mathrm{~s}$, Translation heat in 1990s and the climax with the "Lolita heat" at the beginning of the 21 st century. Compared with abroad Nabokov study, China's research has made certain academic achievements, but also there is a huge space to fill and it has broad research prospects.
\end{abstract}

Keywords-Nabokov; Translation; research; China

\section{INTRODUCTION}

Famous Russian-born American writer Vladimir Nabokov (1899 -1977), was known by the novel "Lolita" (1955) and his masterpiece "Pnin" (1957), "Pale fire "(1962) have laid his status in literary history. Some Western critics said he is the most stylish and most original writer since Joyce.

Translation of Nabokov's work began in the late 1970s, results have been quite obviously through the development until now. I hope that through combing the research history of Nabokov, we can understand the existing research results, current situation and problems, so that on the basis of previous research, we can build a research foundation on the study of Nabokov and Post Modern Russian Literature.

\section{INTRODUCED BY TRANSLATOR}

As the first translator in China's mainland who translated the works of Nabokov, Mei Shaowu translated Nabokov's novel "Pnin" in the late 70s of last century and it was published in the "Foreign literary "magazine in 1978. In 1981, the separate edition of "Pnin" was published by Shanghai Translation Publishing company, which is the second novel Nabokov write based on the United States after "Lolita". It described a travel experience for a Russian old professor Pnin who teaches at American university. Mei Shaowu believes Nabokov is a very important Western writer who was known as the "king of fiction."

In 1985, the American writer John Hersey visited China and when he heard that Mei Shaowu had studied Nabokov's works and had translated "Pnin", he suggested Mei Shaowu to translate Nabokov's best work "Pale Fire" to Chinese readers. Because it is difficult to translate the novel, Mei Shaowu only try to translate some of the chapters, and published them on the

Fund Project: Heihe University 2014 School subject: literature research on Russian Postmodernism, item number: RWY201411; Heihe University young teachers project. 5th of "World Literature" in 1987. Until 1997, he has finished the translated for this 200,000 words book. Nabokov study expert, the translator for "Nabokov Biography" Liu Jialin has written that Mei Shaowu translation of "Pnin," "Pale Fire" and some other short stories are superior translation works for Nabokov, and Mei Shaowu's book "About Nabokov" and " creation of Nabokov's first half of life" are the first of Nabokov thematic research papers in China mainland.

\section{CRITICAL RESEARCH}

Mr. Mei Shaowu wrote "About Nabokov" and "Creation of Nabokov's First Half of Life" in 1987, which were the earliest review articles, and introduced a unique stylish writer to Chinese readers. In 1988, the "Foreign Literature Review" published Luodai's article "Symbol: Reading <Lolita>". This is probably one of the earliest reviews academic articles about "Lolita". This article confirmed the symbolic meaning beyond the moral values of Nabokov novel, it said that the hero of the novel Humbert is "The Embodiment of the Old European Culture", and Lolita is "a symbol of the United States, a symbol of that he cherished, but not as simple as he expected country" Overall, [1] due to the unique nature and personality characteristics of Nabokov creation, so that the beginning of reform and opening up in the face of many Western writers, Chinese academics seems do not have time to pay attention to such a linguistic genius. Thus, from 1981 to 1988, China's Nabokov Translation and research in its infancy, but the publication of "Pnin" and "Laughter in the Dark" These two novels and some review articles publication, also brought a preliminary understanding of Nabokovas a novelist to the readers . This phase has thus become the prelude of "Lolita "Hurricane" since 1989 and last 10 years after.

\section{THE "LOLITA" HURRICANE}

China mainland has set off a translation and reading fashion of "Lolita" since the late 1980s. At that time, Lijiang Publishing Company, Jiangsu Literature and Art Publishing Company, Zhejiang Literature and Art Publishing Company, Hebei People's Publishing Company, Haitian Press and other publishers have launched a number of different Chinese translation versions of "Lolita". "Lolita" Edit Liu Shuoliang from Lijiang Publishing Company recalled that he saw Nabokov and "Lolita" content on a history of foreign literature magazine, and he thought that although "Lolita" has caused controversy in western but it is after all still a tenable work in 
the history of literature. The Translator of this version Huang Jianren first read "Lolita" in 1986 when she was still a graduate student of English Department of Hunan Normal University, and later she spent more than a year to translate the novel. The translator for Jiangsu Literature and Art Publishing Company is $\mathrm{Yu}$ Xiaodan. According to Zhu Wei's working memories who was worked for "people's Literature", Yu Xiaodan's translation is very strenuous, because the novel is full of puns language and allusions, need the look up the dictionary and ask the teacher. Later in 1997 when the era of Art Publishing company publish "Nabokov corpus" and in 2000 when Yilin Publishing company publish "Lolita", they all used Yu Xiadan's translation. In addition, the Chinese translators for "Lolita" also include Peng Xiaofeng, Kong Xiaojiong, Hua Ming, Ren Shengming, Mai Sui, Liao Shiqil. Different versions of "Lolita" are published in different times, and the contents have varying degrees of exclusion. Until 2005, the Shanghai Translation Publishing company published Zhu Wan's translation version of "Lolita," and declared that although "Lolita" has more than 10 Chinese versions but they are the first "full translation" version. The full text is 350 thousand words, "with the most words and without any deletions." This version of "Lolita", has quickly became a bestseller around the country, once again triggered a read boom of "Lolita" and other works of Nabokov.

\section{WORK RESEARCH}

With the rise of domestic Narrative Studies, structure study of Nabokov's works has also become a focus of Nabokov research. "Pnin" is an important work when Nabokov in the United States, many scholars have carried out narrative studies toward this work. Some scholars believe that one of the implied author of "I" narrative position is uncertain, Nabokov let the "I" freely move within the boundaries of narrative level, formed a structure of "big box set of small boxes and snake bites its tail" [4], two stories sometimes coincide, sometimes isolated in order to produce real magic feeling. And some scholars believe that the work "seamless chapter itself, which in turn is formed between each chapter constantly repeated, one singing three sigh, contains changes in repetition,"'both rigorous and constantly swirling rings and progressively spiral " [5]. "Pale Fire" is another highly controversial Nabokov novel. Researchers generally believe that the unique structure of the novel challenges the traditional forms of fiction, innovate the American novel from the form, completed the change the American literature from Modernism to Postmodernism. Therefore, the structure of the text and also the subject of the "Pale Fire" are the focus points of domestic scholars. Some scholars believe that "compare with the traditional 'readable text'," Pale Fire, "as a modern text is a 'writable text', and modern text is pale" [6]. Some scholars have suggested that in the "Pale Fire", "Scheider's poetry as a literary text and Jin Bote's criticism text are interdependent, forming the novel's intertextuality structure; readers appreciate poetry and also read a thrilling story "from Jin Bote's commentary. In addition, "on the surface of these two unrelated story reflects a common theme: self terrible loneliness and try to break through the Lonely" [7]. Nabokov novel study of the structure is related with the domestic
"Narrative hot", but it also reflects outstanding achievement in narrative techniques of Nabokov novels.

\section{THOUGHT RESEARCH}

Nabokov put the focused concern for the ultimate value of art and literature on the aesthetic value of text structure itself and freedom of the human spirit, it contains less of the Russian literary tradition occupy which are mainstream of social significance and moral questioning. These are what the early Russian critics criticized. But external evaluation was not enough to make Nabokov change his ideas, in his eyes, uniquely human creative impulse which contains in the art is the value for literature to settle down, the exploration for the work form and searching for meaning of the individual are his ideals. His inner creative impulse drives his writing rather than anything else. Art make his work monumental rather than anything else.

In Nabokov's consciousness, always lingering the transcendence personal heroism and tragic death of poet Gumilyov. In the 1970s, Nabokov mentioned Gumilyov's death again in a poem: "Gumilyov poetry, how much I love!" As is known, Gumilyov has described or predicted his own death in his poetry more than once - like "one bullet", "a grave in the wilderness" (which exactly match the death of his execution). Gumilyov believe people dead can tell more of a person's essence than people live. He is longing for heroism life, and he is yearning for a more heroic death. The reason why the Nabokov loved Gumilyov so much has a great relationship with the existential implication in his poems. Nabokov has describe the image of Gumilyov in his mind in his United States lecture named "Literature and Art and common sense" about 50 years after his first poem about Gumilyov: he was a hero whose moral is incomparably higher than his executioner; he was an artist full of "noble shore"; he was powerful man who always keep smile while on the road to his execution. The last smile before Gumilyov dead showed his state of consciousness (or inspiration by Nabokov's statement, which is co temporal) is higher than his executioners, because his inspiration got the blessing from other shore, is immortal symbol (Alexander Petrov 267). Nabokov put Gumilyov style "dying smile on the character Godunov - Cherdyn Zaitsev during his work "genius". Character Fedor described the scene of his father been executed, he wrote the dying man "wearing a disdainful smile on his face." In the death moment, still did not forget to care "a pale white moth stands in the dark burdock." Gumilyov's heroism has also been presented in the novel "meritorious". We can see the description matched Gumilyov's death very much.

\section{CONCLUSION}

Overall, during the 30 years from 1980 until now, the research of Chinese academic circles for Nabokov this intercultural bilingual writer, shows a good situation through more attention, more widespread and more good outcomes. To sum up, generally it has the following reflection aspects: First, the research team has grown, not only English and American literature researchers focused on Nabokov, Russian literature researchers have begun to pay more attention to the expatriate 
writer. Secondly, the research range has expanded. From the initial research of "Pnin" to "Lolita", then move to "Pale Fire," "hopeless," "Laughter in the Dark" and other novels, there has been a large number of high quality academic books and papers. In the same time, there are also more and more scholars began to study Nabokov's poetry, biographies, memoirs and literary criticism. Also, research techniques and, research results are remarkable. The new study of Nabokov includes both traditional social and historical criticism, both aesthetic research and theme research. Nabokov study has also entered foreign literature class at college. Nevertheless, China's Nabokov study needs further deepening. Nabokov as an excellent Russian writer, his Russian works, especially the large number of short stories and poems, including some literary criticism, have not been translated into Chinese language. Therefore, China's future study on Nabokov needs to be more systematic, comprehensive and in-depth.

\section{REFERENCES}

[1] Luo Dai: "Symbol: Reading Lolita","literature review" the third issue in 1988.

[2] Tang Xiumin. "Out of the Maze-Understanding Lolita", "literary newspaper" September 23, 1999.

[3] Mou Baizhi. "Reader's maze - the personal experience of analysis about Lolita, "Journal of Guangxi Normal University" (Philosophy and Social Edition) third issue in 2002.

[4] Zhang He. "A complex snake-Brief analysis for narrative structure of Nabokov's novel Pnin, "Contemporary Foreign Literature" the first issue in 2004.

[5] Wang Qingsong. "Discussion about the inner organic structure in Pnin", "literature review" the second issue in 2004.

[6] Chen Ping: "why the fire is pale-Comment for Nabokov 's novel Pale Fire", "literature review" the fourth issue in 2000.

[7] Chen Shidan. "The intertextuality of Pale Fire", "Contemporary Foreign Literature" the fourth issue in 2007. 